\title{
An investigation on the effect of gender on parasite distribution in anurans.
}

\author{
*Omata, Joshua ${ }^{1}$ and Madara Adamu ${ }^{2}$ \\ ${ }^{1}$ Department of Biological Sciences, Faculty of Science, University of Abuja. Nigeria \\ ${ }^{2}$ Department of Biological Sciences, Faculty of Science, University of Abuja. Nigeria \\ *Corresponding Author: omatajoe@yahoo.com \\ DOI: $10.31364 /$ SCIRJ/v6.i9.2018.P0918566 \\ http://dx.doi.org/10.31364/SCIRJ/v6.i9.2018.P0918566
}

\begin{abstract}
Two species of anurans ( Rana temporaria and Bufo bufo) were sampled from 4 different sites in kubwa metropolis of the FCT, Abuja, Nigeria. A total of 172 anurans were collected and the blood and digestive tracks were examined for the presence of haemoparasites and intestinal parasites using thick and thin blood smears and the microscopic examination of the intestine. Blood parasites recovered were Trypanosoma rotatarium and microfilarial worms while intestinal parasites recovered were Oxysomatium sp, Rhabdia sp, Mesoceolium burti, Nyetotherus cordiformis and Opalina ranarum. The results revealed $84.78 \%$ of Rana temporaria were parasitized and $95.34 \%$ of Bufo bufo were parasitized. Males of Rana temporaria were more infected (97.72\%) than the females (72.91\%) while the females (96.07\%) of Bufo bufo were more infected than the males (94.28\%). The prevalence of heamoparasites was dominated by microfilarial worms with $(79.65 \%)$ of the two species of anurans being infected while $(70.34 \%)$ harboured Trypanosoma rotatarium. The prevalence of the intestinal parasites was dominated by Opalina ranarum ( $84.88 \%$ ), followed by Oxysomatium sp (58.72\%), Rhabdia sp (52.32\%), Mesocoelium burti (48.25\%) and Nyetotherus cordiformis (44.18\%) From the results, it was observed that they are no significant relationships between the prevalence and composition of parasites found in the anurans with respect to their gender. This work provides an overview on how anurans can be implicated in the spread of diseases and parasites.
\end{abstract}

Index terms: Anurans, Rana temporaria, Bufo bufo, Parasites, Prevalence and Gender.

\section{INTRODUCTION}

Anurans belongs to the order anura(salientia) of the class of vertebrates known as amphibians comprising the frogs, toads, and tree frogs all of which lack a tail in the adult stage and have long hind limbs often suited to leaping and swimming either in water or on land. (Blaustein et al., 1994; Berger et al., 1998; Daszak et al., 2000; Kiesecker et al., 2001).

Frogs are affected by bacteria, viral organisms, heamoparasites, protozoans and worms. Wide distribution of blood parasites hosted by amphibians has been reported (Bardsley and Harmsen, 1973).

Anurans are definitive hosts to several classes of helminth parasites including cestoda, monogenea, Trematoda, Nematoda and Acanthocephala. Apart from this established role, anurans also serve as intermediate hosts (Sessions and Ruth, 1990), or as paratenic hosts (Thierman and Wassersug, 2000) in the tropical transmission of helminth infections to a number of vertebrate hosts. Reports of these alternative roles have received the attention of various investigators in Europe (Okulewics, 2008), Canada (Thierman and Wassersug, 2000), USA (Sessions and Ruth, 1990; Ebenhard and Brandt, 1995) and South America ( Torres and Puga, 1996). Except for the report of Jackson and Tinsley (1998), discussing the use of anurans as transport hosts in camallanid nematode life cycle, there is a dearth of information on this phenomenon in Africa.

\section{MATERIALS AND METHODS}


A total of 172 anurans consisting of two species (Rana temporaria and Bufo bufo) were examined and screened for the presence of heamoparasites and intestinal parasites. Anurans were collected from the kubwa metropolis of the FCT, Abuja, Nigeria (Fig. 1) from September, 2016 to February, 2017.

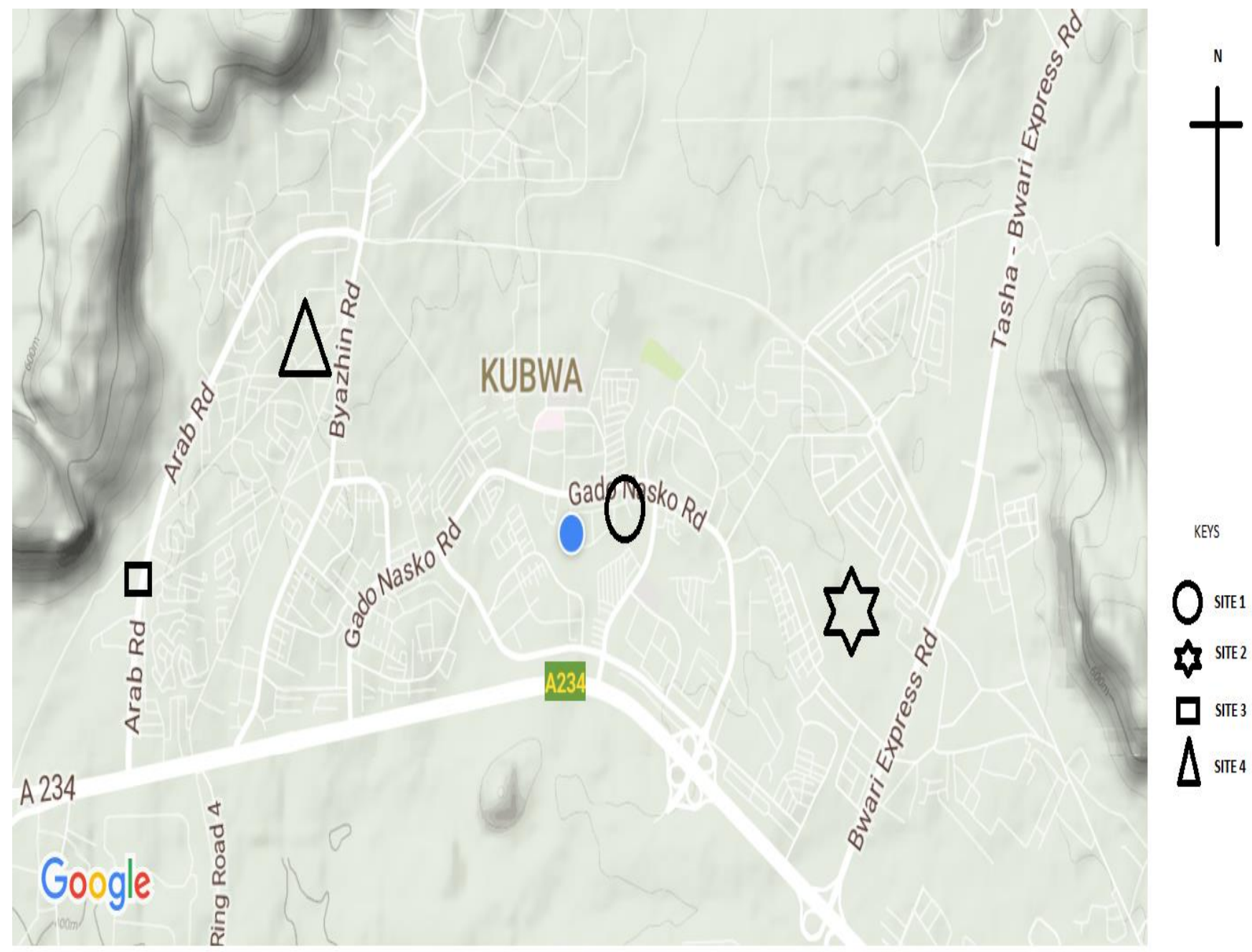

Figure 1: Map of Kubwa

Source: Google Maps

Specimens of Rana temporaria and Bufo bufo were randomly collected from 4 different sites in the kubwa metropolis. Hand nets were used to capture the animals and plastic containers were used to house live anurans and then transported to the laboratory for examination. (Crumb and Scott, 1994).

In the laboratory, the anurans were euthanized with chloroform. Blood samples were collected from the heart with syringes. Thick and thin blood smears were prepared to determine the presence of haemoparasites. The blood slides were air-dried, methyl alcohol was used to fix them and thereafter stained with Giemsa.

The intestine was placed in a petri dish filled with water. It was then cut open along its length and its linings scraped with a scalpel and the contents were examined for parasites. Yamaguti (1971) descriptions were used in identifying the parasites.

\section{RESULTS}

A total of $178(100.00 \%)$ anurans were collected, consisting of $86(48.30 \%)$ Bufo bufo and 92(51.70\%) Rana temporaria. The results revealed $84.78 \%$ of Rana temporaria were parasitized and $95.34 \%$ of Bufo bufo were parasitized. Males of Rana temporaria were more infected $(97.72 \%)$ than the females $(72.91 \%)$ while the females $(96.07 \%)$ of Bufo bufo were more infected than the males $(94.28 \%)$. The prevalence of heamoparasites was dominated by microfilarial worms with (79.65\%) of the two species of anurans 
being infected while (70.34\%) harboured Trypanosoma rotatarium. The prevalence of the intestinal parasites was dominated by Opalina ranarum ( $84.88 \%$ ), followed by Oxysomatium sp ( 58.72\%), Rhabdia sp (52.32\%), Mesocoelium burti (48.25\%) and Nyetotherus cordiformis (44.18\%)

The total number of Bufo bufo collected was 86 (100.00\%), consisting of 35(40.70\%) males and 51(59.30\%) females. The microfilarial worms and the trypanosoma rotatarium are the two species of blood parasites found parasitizing the anurans in this study. 33(38.40\%) male Bufo bufo harboured microfilarial worms while 49 (57.00\%) female Bufo bufo harboured microfilarial worms. A total of $82(95.30 \%)$ out of $86(100.00 \%)$ Bufo bufo examined harboured microfilarial worms. 21 (24.40\%) male Bufo bufo harboured Trypanosoma rotatarium while 34 (39.50\%) female Bufo bufo harboured Trypanosoma rotatarium. A total of 55(64.00\%) out of $86(100.00 \%)$ Bufo bufo harboured Trypanosoma rotatarium.

Specimens of Rana temporaria collected, consists of 38(41.30\%) males and 54(58.69\%) females bringing the total specimens collected to $92(100.00 \%)$. 32(34.78\%) male Rana temporaria harboured microfilarial worms while 23(25.00\%) female Rana temporaria harboured microfilarial worms. A total of 55 (59.78\%) anurans out of the $92(100.00 \%)$ Rana temporaria examined harboured microfilarial worms. 41 (44.56\%) male Rana temporaria harboured Trypanosoma rotatorium while 25 (27.17\%) female Rana temporaria harboured Trypanosoma rotatorium. A total of 66 (71.73\%) out of 92(100.00\%) Rana temporaria examined, harboured Trypanosoma rotatorium. The blood parasites observed in Bufo bufo and Rana temporaria are presented below in relation to the age and sex of the anurans respectively:

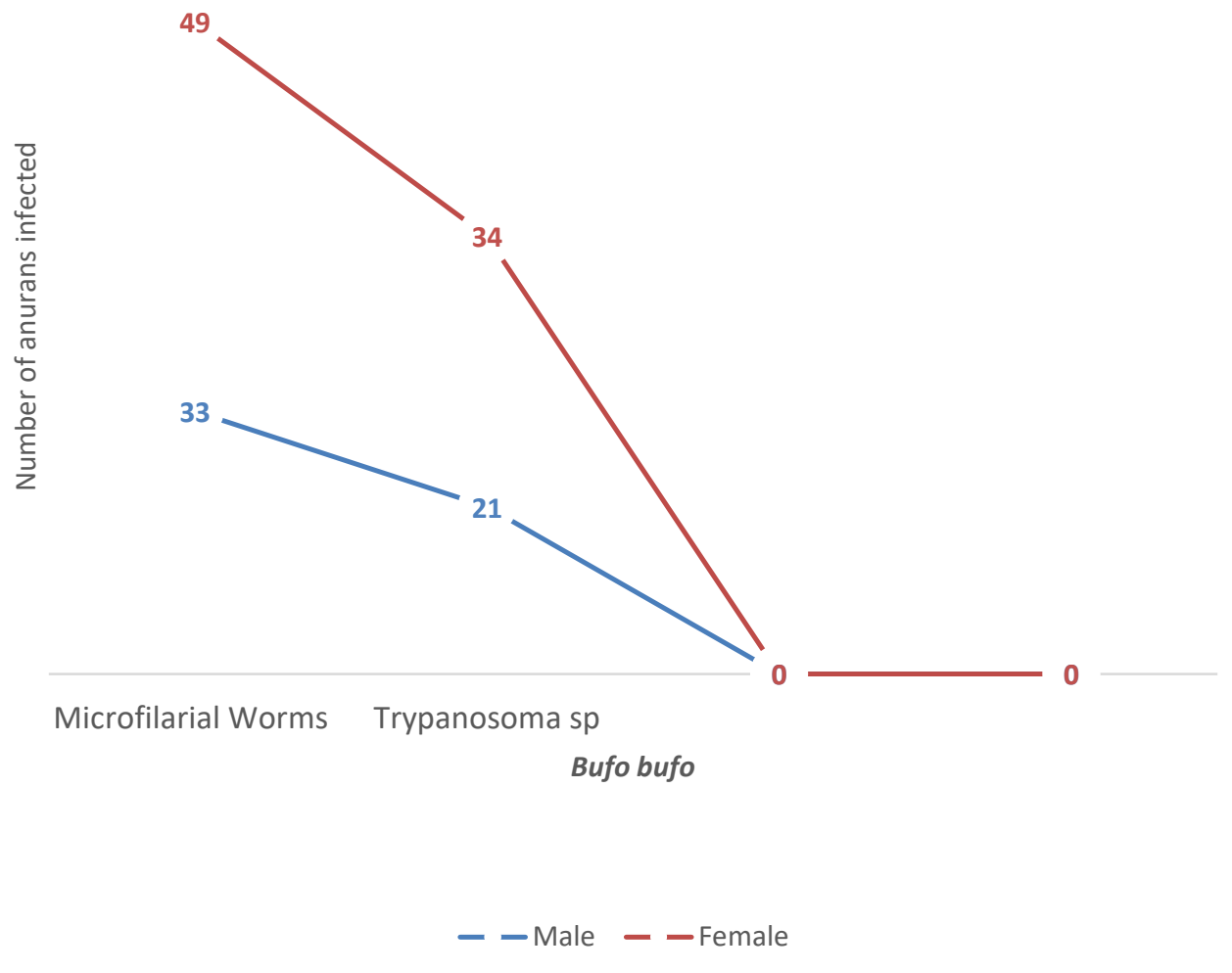

Figure 2: Number of anurans infected with blood parasites based on gender in Bufo bufo 


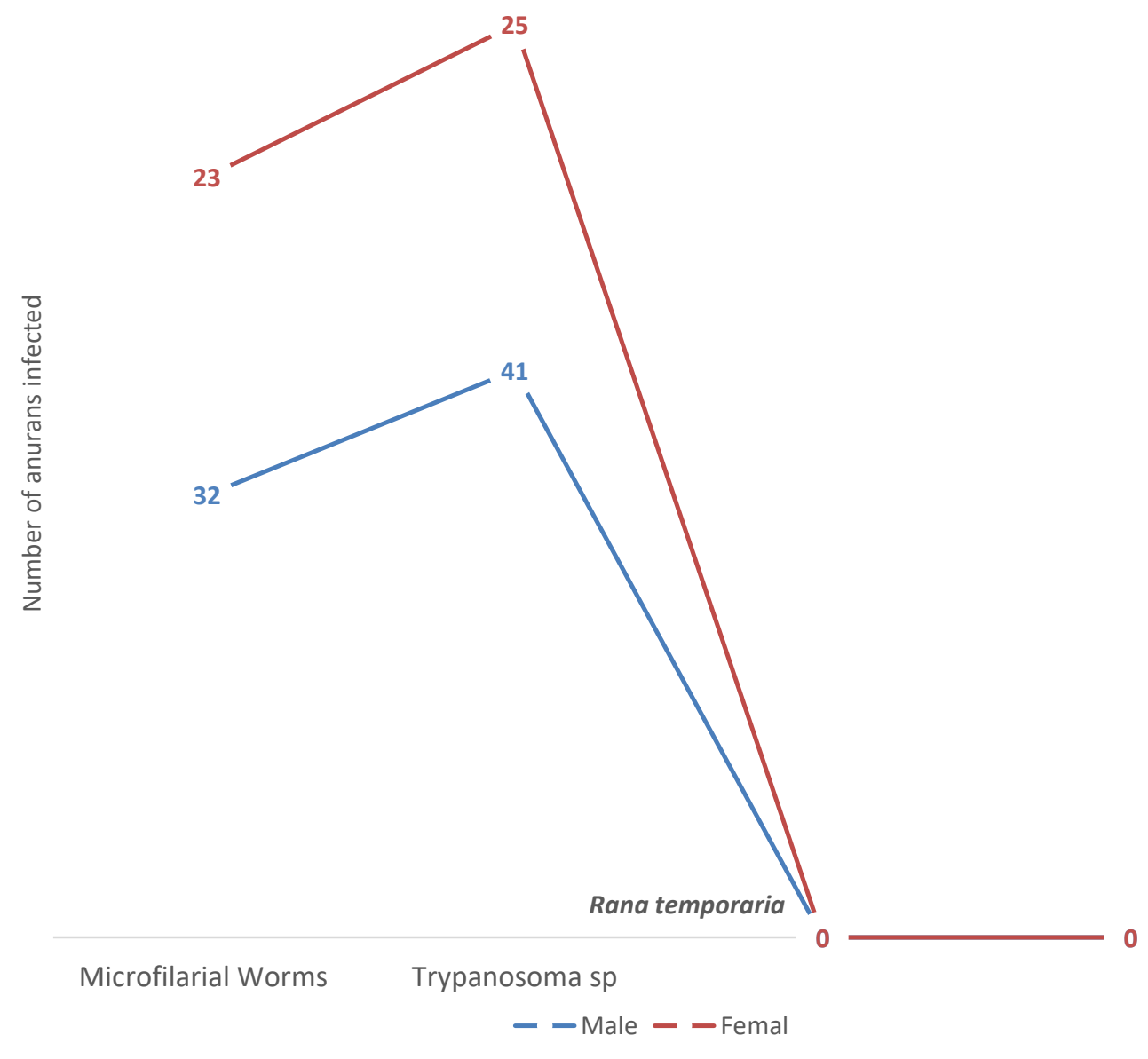

Figure 3: Number of anurans infected with blood parasites based on gender in Rana temporaria.

A total of 5 species of intestinal parasites were encountered in this study. Oxysomatium sp was present in 43 (50.00\%) of the Bufo bufo examined. Rhabdia sp was present in a total of 42 (48.83\%) of the Bufo bufo examined. Mesoceolium burti was present in 29 (33.72\%). 42 (48.83\%) Bufo bufo examined harboured Nyetotherus cordiformis. Opalina ranarum belonging to the family Opalinidea was present in 68 (79.01\%) Bufo bufo representing the largest number of anurans harbouring a particular parasite in the group

Oxysomatium $s p$ was present in 58 (63.04\%) Rana temporaria . Rhabdia sp was equally present in 48 (52.17\%) Rana temporaria. Mesoceolium burti was found in 54(58.69\%). 34 (36.95\%) Rana temporaria harboured Nyetotherus cordiformis. Opalina ranarum was present in 78 (84.78\%) Rana temporaria. Below are graphical representations of the parasites in Rana temporaria: 


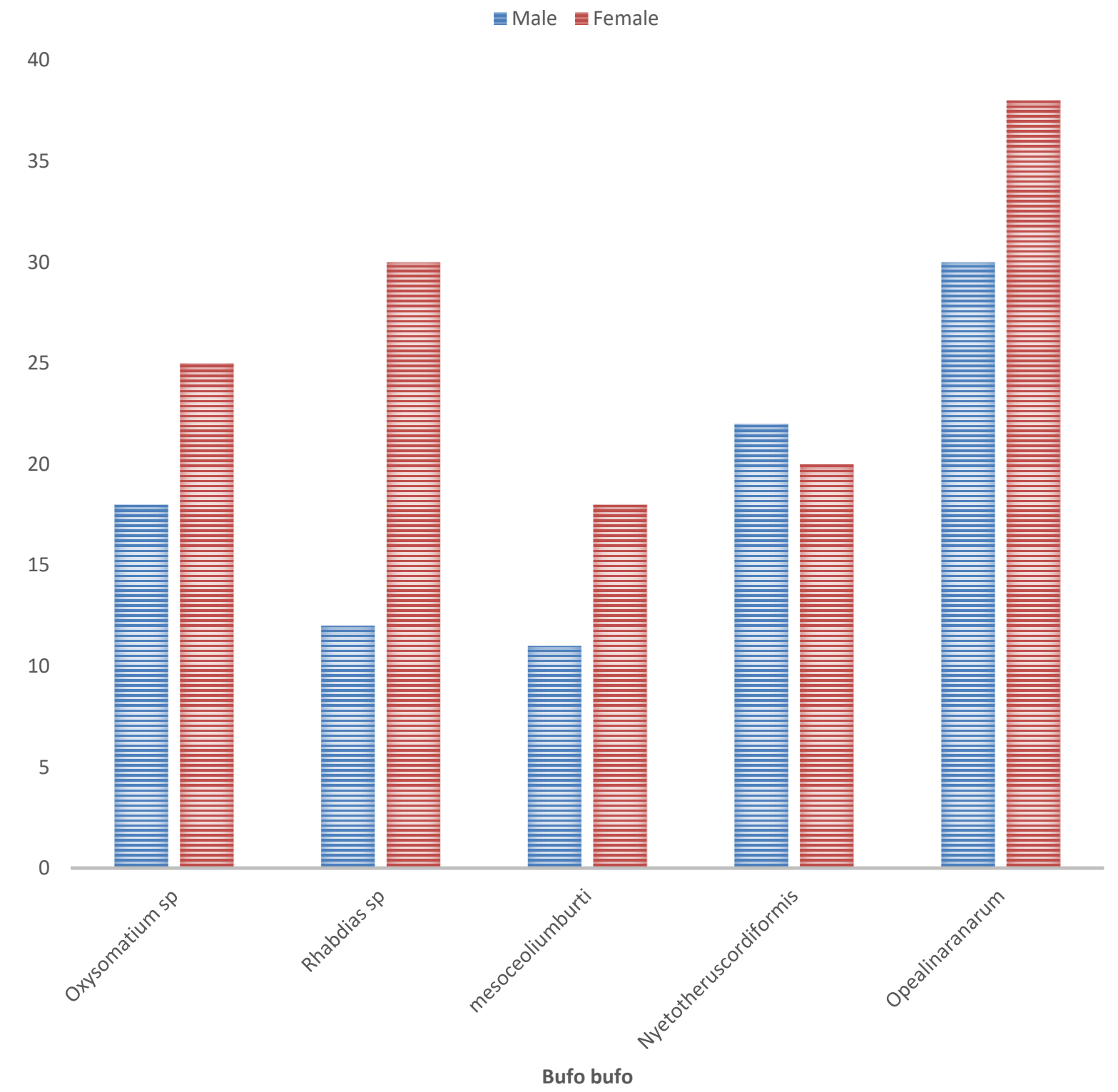

Figure 4: Number of anurans infected with intestinal parasites based on gender in Bufo bufo. 


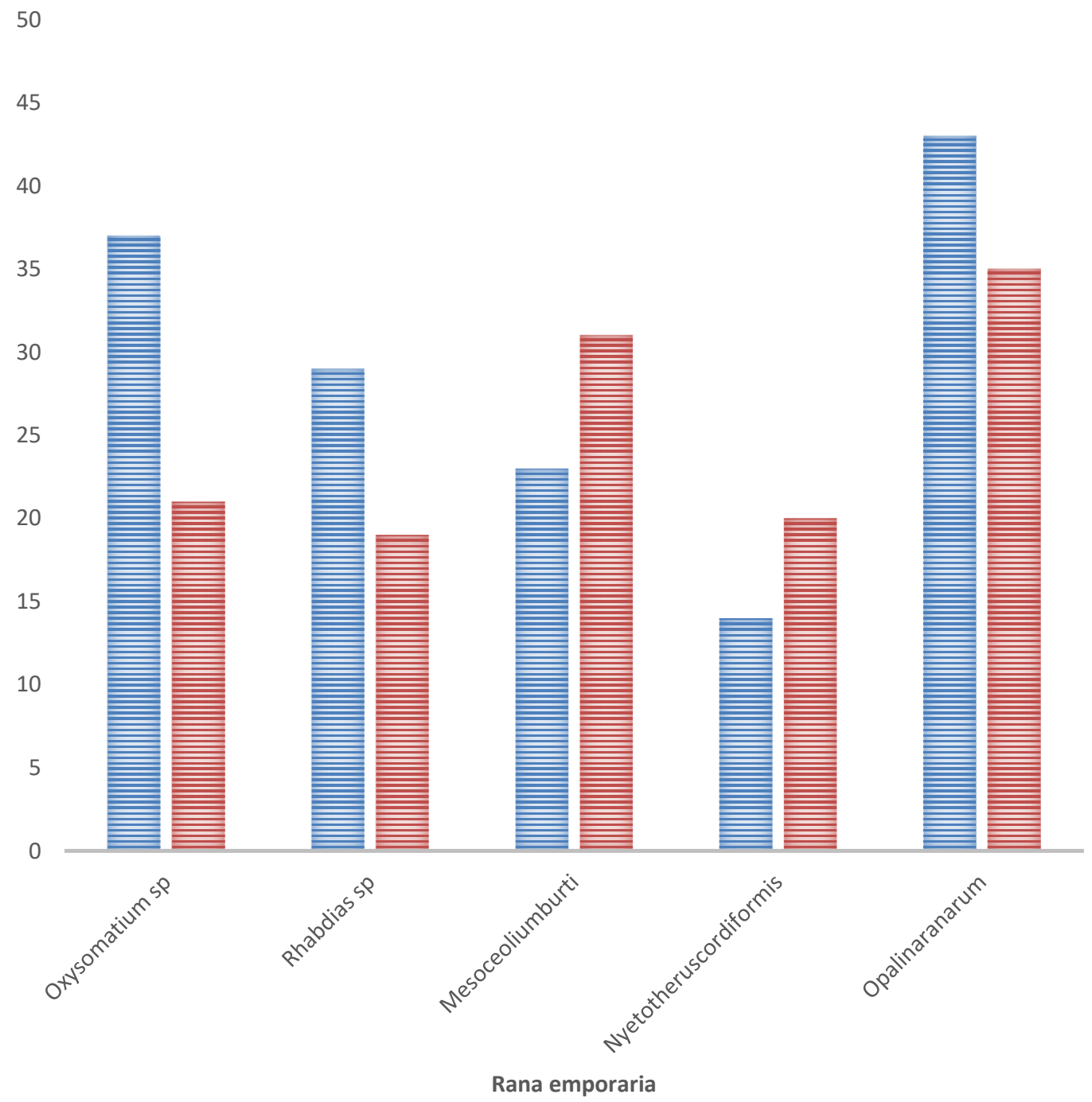

Figure 5: Number of anurans infected with intestinal parasites based on gender in Rana temporaria. 


\section{DISCUSSION}

Seven different species of parasites were observed in the anurans collected in this study. Out of the seven species collected, two species were blood parasites while five species of the parasites examined were intestinal parasites.

The results encountered in this study are in tandem with the findings of Aisien and Braimoh (2003) as well as the observations of Naciye and Ismail (2000). The habitat of anurans which include both the aquatic and terrestrial habitats suggests the reason for the abundance and presence of the various parasites that these organisms harbour.

Basically, the anurans co-habit the same habitat and live in close proximity with other animals that also serves as hosts to some of the observed parasites therefore serving as a reason for the abundance and presence of the parasites found in the anurans.

There was no significant relationship between the prevalence of parasites in female members of Rana temporaria and the male counterparts of Rana temporaria, since the p-value was obtained to be 0.506 which is greater than $0.05(95 \%)$ level of significance.

The results also revealed that there was no significant difference observed in the prevalence of parasites in the female and male members of Bufo bufo. The p-value was obtained to be 0.249 which is greater than 0.05 (95\%) level of significance. This suggests that the distribution and prevalence of parasites in the anurans is not affected by their gender.

The p-value for the overall prevalence of parasites in Bufo bufo and Rana temporaria was obtained to be 0.317 which is greater than $0.05(95 \%)$ level of significance, which shows that no correlation or relationship exists between the prevalence of the parasites in the both species. This is a result of the two species being exposed to similar environmental conditions as well as inhabiting similar ecological niche, basically what this results shows is that both species exhibits similar patterns as it relate to the abundance and prevalence of blood and intestinal parasites.

The results equally revealed that there is a significant relationship observed in the prevalence of parasites in male Bufo bufo and male members of Rana temporaria, since the p-value was obtained to be 0.044 which is less than $0.05(95 \%)$ level of significance. This shows that a difference exists in the abundance and composition of paraistes between the male members of the two species of anurans examined. This is as a result of varying durations of attachment to the body of the female anurans by the male anurans which continually exposes them to myriads of parasites.

\section{REFERENCES}

[1] Adakayi P.E . (2000). Climate of FCT. In: Dawam P.D (Ed.) Geography of Abuja, Federal Capital Territory.Famous/Asanlu Publishers, Minna. Pp 37-39

[2] Aisien, S.O., Ayeni, F. And Braimoh, K. (2003).Helminth parasites of anurans from the Savannah-mosaic zone southwestern Nigeria. Acta Parasitologica.48 (1)47-54

[3] Balogun, O. (2001) The Federal Capital Territory: A Geography of its Development. Ibadan University Press,Nigeria.

[4] Bardsley, J.E. and Harmsen, R. (1973).The trypanosomes of Anura. Advanced Parasitology.11: 70-73.

[5] Berger, L., Spear, R., Daszak P., Green D., Cunningham A.A., Goggin C.L.,Slocombe, R., Ragan, M.A., Hyatt A.D., McDonald, K.R., Hines H.B., Lips, K.R., Marantelli, G. and Parkes, H. (1998). Chytridiomycosis causes amphibian mortality associated with population declines in the rainforests of Australia and Central America. Proceedings of the National Academy of Science. 95:9031-9036

[6] Blaustein, A.R., David B. H. and Wayne P.S. (1994). Amphibians

Declines: Judging Stability, Persistence and Susceptibilty of Populations to $8(1), 60-71$

[7] Crump, M. and Scott, N. (1994). Visual Encounters Survey. In:Measuring and Monitoring Biological Diversity- standard methods for amphibians, Hayer, M., Donnelly, M., McDiarmid, R., Hayek, L. and Foster, M. (Ed.),84-91, Smithsonian Institution Press,ISBN-10 1560982845, Washington, United States of America. 
[8] Daszak, P., Cunningham, A.A. and Hyatt, A.D (2000). Emerging infectious diseases of wildlife- threats to biodiversity and human health. Science. 287:443-449

[9] Ebenhard, M.L. and Brandt, F.H. (1995). The role tadpoles and frogs asparatenic hosts in the lifecycle of Dracunculus insignis. Journal of Parasitology. 81(5)792-793.

[10] Jackson, J. A. and Tinsley, R. C. (1998). Reproductive interference in the concurrent infections of two protopolystoma species ( Monogenea: Polystomatidae). International Journal of Parasitology. 28 (8): 1201-1204

[11] Kiesecker, J. M., A. R. Blaustein, and L. K. Belden. (2001).Complex causes of amphibian population declines. Nature 410:681-684.

[12] Naciye, G.S. \& Ismail, Y. (2000). The ciliate fauna in the digestive system of Rana ridibunda (Amphibia: Anura)-II Nyctotherus (Nyctotheridae: Heterotrichida). Turkish Journal of Zoology 24: 245-252

Nigeria Geographic Name base (2016). Kubwa Retrievedfrom:[http://nga.geonamebase.com/node/49310] Accessed $1^{\text {st }}$ April, 2016

[14] Okulewics , A. (2008). The role of paratenic hosts in the life cycles of helminthes. Wiadomosci Parazytologiczne. 34(4):297301

[15] Sessions, S.K. \& Ruth, S.B. (1990).Explanation for naturally occurring supernumerary limbs in amphibians. Journal of Experimental Zoology. 254, 38-47.

[16] Thiemann,G. W. And Wassersug,R. J. (2000).Biased distribution of trematode metacercariae in the nephric system of Rana tadpoles. Journal of Zoology. 252(4),534-538

[17] Torres, P. and Puga. S. (1996). Occurrence of cystacanths of centrorhyncus sp. In toads of the genus Eusophusin Chile. Memorias do Institudo Oswaldo cruz. 91(6)717-719

[18] Yamaguti, S. (1971).Synopsis of Trematodes of Vertebrates. Tokyo: Keigaku Publications Company, 633pp.

[19] Yamaguti, S. (1963).Parasitic Copepoda and Branchuira of fishes. Interscience Publishers, New York. 1104p

[20] Zickus, T. (2002).The first data on the fauna and distribution of blood parasites of amphibians in Lithuania. Acta Zoologica Lituanica, 12(2): 197-202. 